\title{
Acidic extracellular microenvironment and cancer
}

\author{
Yasumasa Kato ${ }^{1 *}$, Shigeyuki Ozawa ${ }^{2}$, Chihiro Miyamoto ${ }^{3}$, Yojiro Maehata $^{3}$, Atsuko Suzuki ${ }^{1}$, Toyonobu Maeda \\ and Yuh Baba ${ }^{4}$
}

\begin{abstract}
Acidic extracellular pH is a major feature of tumor tissue, extracellular acidification being primarily considered to be due to lactate secretion from anaerobic glycolysis. Clinicopathological evidence shows that transporters and pumps contribute to $\mathrm{H}^{+}$secretion, such as the $\mathrm{Na}^{+} / \mathrm{H}^{+}$exchanger, the $\mathrm{H}^{+}$-lactate co-transporter, monocarboxylate transporters, and the proton pump ( $\mathrm{H}^{+}$-ATPase); these may also be associated with tumor metastasis. An acidic extracellular pH not only activates secreted lysosomal enzymes that have an optimal pH in the acidic range, but induces the expression of certain genes of pro-metastatic factors through an intracellular signaling cascade that is different from hypoxia. In addition to lactate, $\mathrm{CO}_{2}$ from the pentose phosphate pathway is an alternative source of acidity, showing that hypoxia and extracellular acidity are, while being independent from each other, deeply associated with the cellular microenvironment. In this article, the importance of an acidic extracellular $\mathrm{pH}$ as a microenvironmental factor participating in tumor progression is reviewed.
\end{abstract}

Keywords: Acidic microenvironment, Cancer, Malignant phenotype

\section{Introduction}

The extracellular $\mathrm{pH}\left(\mathrm{pH}_{e}\right)$ of tumor tissues is often acidic [1], and acidic metabolites, e.g. lactic acid caused by anaerobic glycolysis in hypoxia, seem to be the main cause. Accumulating evidence shows that an acidic microenvironment is a regulator of cellular phenotype. Whereas $\mathrm{Na}^{+}-\mathrm{HCO}_{3}^{-}$co-transporter and $\mathrm{Cl}^{-} / \mathrm{HCO}_{3}^{-}$exchanger contribute a fall in intracellular $\mathrm{pH}$, the $\mathrm{Na}^{+} / \mathrm{H}^{+}$exchanger (NHE) [2], the $\mathrm{H}^{+}$-lactate co-transporter, monocarboxylate transporters (MCTs), and the $\mathrm{H}^{+}$-ATPase $\left(\mathrm{H}^{+}\right.$pump) are responsible for the secretion of $\mathrm{H}^{+}$[3]. Because carbonic anhydrase (CA) is widely distributed and can form $\mathrm{H}^{+}$by catalyzing hydration of $\mathrm{CO}_{2}$, an excess amount of $\mathrm{CO}_{2}$ production through the pentose phosphate pathway in tumor cells is an alternative cause of a lower $\mathrm{pH}$ [4]. Acidic $\mathrm{pH}_{e}$ increases not only the activation of some lysosomal enzymes with acidic optimal $\mathrm{pH}$, but also the expression of some genes involved with pro-metastatic factors. When melanoma cells pretreated with an acidic medium were injected into the tail vein of mice, a significantly higher frequency of them metastasized to the lungs [5].

\footnotetext{
* Correspondence: yasumasa-kato@umin.ac.jp

${ }^{1}$ Department of Oral Function and Molecular Biology, Ohu University School of Dentistry, 963-8611, Koriyama, Japan

Full list of author information is available at the end of the article
}

Thus, an acidic microenvironment is closely associated with tumor metastasis.

Acidity is found at the surface of skin and in inflammatory sites. It is also associated with bone resorption. Thus, an acidic microenvironment plays a role of homeostasis and the immune defense system. We will review the roles of acidic $\mathrm{pH}_{e}$ in tumor progression along with other physiological and pathological conditions.

\section{Lactate and tumor}

The "Warburg effect" is a well-accepted theory that says that tumors tend to produce lactate by using the anaerobic glycolytic pathway, even in the presence of sufficient oxygen, rather than oxidative phosphorylation for energy production [1]. High lactate levels indicate metastases, tumor recurrence, and prognosis in some cancer patients [6-9]. In the molecular mechanism relating to these clinical contributions, lactate from tumor cells contributes to their immune escape. High lactate secretion from tumor cells inhibits its export from $\mathrm{T}$ cells, thereby disturbing their metabolism and function [10]. Tumor-derived lactate affects inflammation and immune deficiency of tumor cells. Lactate itself functions as an intrinsic inflammatory mediator that increases interleukin (IL)-17A production by T-cells and macrophages, resulting in the promotion of chronic inflammation in 
tumor microenvironments [11]. Lactate inhibits dendritic cell activation during antigen-specific autologous T-cell stimulation [12]. It also enhances the motility of tumor cells and inhibits monocyte migration and cytokine release [13]. It can contribute to angiogenesis through induction of IL-8 via nuclear factor- $\mathrm{KB}$ (NF-kB) [14] and induction of vascular endothelial growth factor (VEGF/VEGF-A) via hypoxia-inducible transcription factor (HIF)-1 [15]. Furthermore, lactate production contributes to radioresistance of tumors due to its antioxidant properties [16].

Inhibition of the lactate transporter has been considered a potential new therapeutic strategy. For example, $\alpha$-cyano-4-hydroxycinnamate, a specific inhibitor of the lactate transporter MCT1, suppresses tumor angiogenesis [17]. Quercetin (CYP2C9), which is an inhibitory flavonoid, inhibits lactate transport and acts as a hyperthermic sensitizer of HeLa cells [18].

\section{Appearance of acidic microenvironments under physiological and pathological conditions}

An oncogenic transformation assay by oncogenic-virus infection shows that lactate production is correlated with an increase in the number of transformed foci by viral infection in a presence of $5 \% \mathrm{CO}_{2}$ in $95 \%$ air [19]. Since high lactate corresponds to a high proton concentration, an acidic $\mathrm{pH}_{e}$ is a major feature of the solid tumor tissue [1,20-22]. Lactic acid is a product of the anaerobic glycolysis including the activity of lactate dehydrogenase (LDH) 5 that generates lactic acid from pyruvate and the expression of which has been strongly associated with the poor prognosis of patients with non-small cell lung $[23,24]$ and colorectal cancers [25-27].

$\mathrm{CO}_{2}$ is a major source of acid in glycolytically impaired mice [4]. The pentose phosphate pathway is seen as a major productive pathway for $\mathrm{CO}_{2}$ which can be processed to $\mathrm{H}^{+}$and $\mathrm{HCO}_{3}^{-}$by the catalytic activity of CA. In osteoclasts, CA II, a CA isozyme, is a major enzyme producing $\mathrm{H}^{+}$to decalcify bone hydroxyapatite. Osteoclasts secrete $\mathrm{H}^{+}$and create an acidic microenvironment below pH 5.5, which is critical for the bone resorption $[28,29]$ and the proton can be secreted through $\mathrm{H}^{+}$-ATPase [30]. Induction of CA II expression itself is also induced by an acidic $\mathrm{pH}_{e}$ [31]. Thus, secretion of acidic metabolites and/or the pentose phosphate pathway-mediated $\mathrm{CO}_{2}$ production, and CA-mediated production of $\mathrm{H}_{2} \mathrm{CO}_{3}$ form acidic microenvironments.

Extracellular acidity is a pathological feature of inflammation [32] and solid tumor tissue [1,20-22]. Acidity in inflammatory tissue is due to production of proton from macrophages, whereas tumor tissue acidity is due to acidic metabolites, e.g., lactate, caused by anaerobic glycolysis under the hypoxia [20-22,33]. The acidic microenvironment acts as a trigger for pain in both inflammation $[34,35]$ and in cancer patients [36].
Ovarian cancer G-protein-coupled receptor 1 (OGR1), a receptor for sphingosylphosphorylcholine, and GPR4, a close relative of OGR1, also act as a proton-sensing receptor in osteosarcoma cells and primary human osteoblast precursors [37]. OGR1 (GPR68) stimulates cyclooxygenase2 expression and prostaglandin (PG) $\mathrm{E}_{2}$ production in response to acidic $\mathrm{pH}_{e}$ in a human osteoblastic cell line [38]. Because $\mathrm{PGE}_{2}$ is involved in osteoclastic differentiation of precursor cells [39], inhibition of the OGR1 signaling negatively regulates osteoclastogenesis [40]. Another type of G-protein-coupled receptor, TDAG8 (GPR65), also senses $\mathrm{pH}_{e}[41,42]$.

Breast cancer frequently metastasizes to bone. Osteoclasts can be activated by breast cancer-derived $\mathrm{H}^{+}$such that osteolysis occurs when cancer cells metastasize to bone [36]. During this process, patients feel pain through acidsensing ion channels (ASIC) $1 \mathrm{a}, 1 \mathrm{~b}$ and $3[36,43,44]$.

An acidic $\mathrm{pH}_{e}$ is also found in the epidermis and plays an important protective role against bacterial infection [45-47]. Using the conditional knockout (KO) mice for focal adhesion kinase (FAK) in keratinocytes, Ilic et al. [47] showed that the stratum corneum $\mathrm{pH}_{e}$ gradient of keratinocytes in these mice had significantly more neutral $\mathrm{pH}$ values, and that NHE1 failed to localize to the plasma membrane [47]. Thus, FAK controls pH-dependent epidermal barrier homeostasis by regulating actin-directed NHE1 plasma membrane localization [47].

Lung liquid is acidic [48], which is worse in patients with cystic fibrosis [49], although the airway $\mathrm{pH}$ is not known for certain because different detecting methods have been used [50].

\section{CA expression in cancer}

$\mathrm{CA}$ isoforms are associated with tumor malignancy, including CA I [51], CA II [51,52], CA IX [53,54], CA XII [55], and CA XIII [56]. Among them, CA IX in particular has been well studied in association with hypoxia and tumor survival through regulating intracellular $\mathrm{pH}[53,57]$. In ovarian cancer, high expression of CA IX with a concomitant increase in VEGF-A is associated with overall survival rates positively [58]. Overexpression of CA IX increases tumor cell migration and invasion [59]. CA inhibitor suppresses invasion of renal cancer cells in vitro [60]. Based on the accumulated evidence, a new therapeutic strategy targeting CA has been considered [61-63].

\section{Acidic $\mathrm{pH}_{e}$ activates proteinase activity and induces gene expression}

Acidic $\mathrm{pH}_{e}$ activates some proteinases. Although caries is due to some bacterial acidic metabolites, Tjäderhane et al. [64] found that host-derived pro-matrix metalloproteinase9 (proMMP-9), proMMP-2 and proMMP-8 in saliva could be activated by acid, and thereby suggested that these MMPs contribute to the disruption of dentin in caries. 
Alternatively, host derived proMMP-9 could be activated in the stomach, and this suggests it functions as a digestive enzyme for collagenous foods [65,66]. Activation of proMMP-9 by an acidic $\mathrm{pH}_{e}$ also occurs in a human melanoma model [67].

Lysosomal enzymes have an acidic optimal $\mathrm{pH}$. Some tumor cells have the ability to secrete them, such as cathepsin B and cathepsin L [5]. Cathepsin K plays an important role in osteoclast-mediated bone resorption $[68,69]$; its inhibition prevents breast cancer-induced osteolysis and skeletal tumor burden [70]. Thus, osteoclastmediated acidic $\mathrm{pH}_{e}$ leads to mineral dissolution and activation of cathepsins to digest bone matrix, such as type I collagen. Podgorski et al. [71] reported that SPARC/ osteonectin, a major non-collagenous protein in bone, is digested by cathepsin $\mathrm{K}$ and its fragments are associated with bone-metastasis. Another lysosomal enzyme, heparanase, has an acidic optimal $\mathrm{pH}$; it degrades heparan sulfate in the basement membrane and contributes to tumor invasion and metastasis [72,73].

Also, acidic microenvironments affect the expression of some genes, such as MMP-9 [74,75] and acidic sphingomyelinase in mouse B16 melanoma [74], plateletderived endothelial cell growth factor (thymidine phosphorylase) in human breast cancer cells [76], the inducible isoform of nitric oxide synthase (iNOS) in macrophages [77], VEGF-A in glioma [78] and glioblastoma [79] cells, and IL-8 expression in human pancreatic adenocarcinoma [80-82] and ovarian carcinoma cells [83].

\section{Acidic $\mathrm{pH}_{e}$ signal transduction pathway}

Thus, although acidic $\mathrm{pH}_{e}$ occurs in several physiological and pathological conditions, information on its signaling remains limited. Transcription factors AP-1 and NF- $\kappa B$, independent of hypoxia, have important roles in the acidic $\mathrm{pH}_{e}$-induced expression of VEGF-A [78,84] and IL-8 [80-83,85]. p38 mitogen-activated protein kinase (MAPK) is involved in acidic $\mathrm{pH}_{e}$ signaling that induces IL-8 [85].

We also found involvement of phospholipase D (PLD) in the acidic $\mathrm{pH}_{e}$-intracellular signaling to induce MMP9 production $[75,86]$. Acidic $\mathrm{pH}_{e}$-induced PLD activation was prolonged for at least for $24 \mathrm{~h}$, different from general growth factor signaling. Inhibition of PLD activity by 1-butanol and Myr-ARF6 suppresses acidic $\mathrm{pH}_{e}$-induced MMP-9 expression [87]. Acidic $\mathrm{pH}_{e}$ increases the steady-state levels of phosphorylated ERK1/2 and p38, and PLD inhibitors prevent these increases. Using $5^{\prime}$-deleted constructs of the MMP-9 promoter, we found that the acidic $\mathrm{pH}_{e}$-responsive region was located at nucleotides -670 to -531 , a region containing the NF- $\mathrm{kB}$ binding site. A mutation in the $\mathrm{NF} \kappa \mathrm{B}$ binding site reduced acidic $\mathrm{pH}_{e}$-induced MMP-9 promoter activity, and NF$\kappa \mathrm{B}$ activity was induced by acidic $\mathrm{pH}_{e}$. Pharmacological inhibitors specific for MEK1/2 (PD098059) and p38 (SB203580) attenuated acidic $\mathrm{pH}_{e}$-induced NF- $\mathrm{kB}$ activity and MMP-9 expression. The data suggest that PLD, MAPKs including ERK $1 / 2$ and p38, and NF-kB mediate acidic $\mathrm{pH}_{e}$ signaling thereby inducing MMP-9 expression. Activation of ERK1/2 and p38, followed by the NF- $\mathrm{kB}$ axis, which is stimulated by tumor necrosis factor- $\alpha$ (TNF- $\alpha$ ), also occurs in cholangiocarcinoma [88]. This suggests that acidic $\mathrm{pH}_{e}$ signaling is, at least in part, the signaling pathway for TNF- $\alpha$. However, it has been reported that acidic $\mathrm{pH}_{e}$ activates $\mathrm{p} 38$, but not ERK1/2, in T-cell receptor signaling in Jurkat cells [89]. This may be cell-type specific. In a further contribution dealing with the intracellular substances of acidic $\mathrm{pH}_{e}$, we have found that calcium influx triggers acidic $\mathrm{pH}_{e}$-induced PLD activation and that acidic sphingomyelinase mediates acidic $\mathrm{pH}_{e}$ signaling to activate NF- $k B$ independently of the PLD-MAPK pathway [74].

OGR1 stimulates cyclooxygenase-2 expression and $\mathrm{PGE}_{2}$ production in response to an acidic $\mathrm{pH}_{e}$ in a human osteoblastic cell line through G(q/11)/phospholipase $\mathrm{C} /$ protein kinase $\mathrm{C}$ pathway [38] and in human aortic smooth muscle cells through the phospholipase $\mathrm{C} /$ cyclooxygenase $/ \mathrm{PGI}_{2}$ pathway [90].

Acidic $\mathrm{pH}$ directly affects transcription factor activity; DNA binding activity of the transcription factor, SP1, is enhanced by intracellular acidic $\mathrm{pH}$ [91]. Intracellular $\mathrm{pH}$ is maintained a constitutively neutral state but known to become transiently acidic when $\mathrm{pH}_{e}$ decreases to acidic. Therefore an acidic $\mathrm{pH}$ can activate SP1.

\section{Acidic $\mathrm{pH}_{e}$ stimulates disruption of adherence junctions}

When tumor cells move into their surrounding tissue, cell-cell junctions become dissociated. Acidic $\mathrm{pH}$ disrupts adherence junction by $\mathrm{Src}$ activation, resulting in E-cadherin degradation through the protein kinase $\mathrm{C} \delta$ pathway [92,93]. Acidic $\mathrm{pH}_{e}$ also induces motility of tumor cells, and inhibits monocyte migration and cytokine release [13].

\section{Acidic $\mathrm{pH}_{e}$ stimulates metastatic potential}

Brockton et al. [54] have shown that high stromal CA IX expression is associated with nodal metastasis. The high activity produces an acidic microenvironment that leads to increased metastatic ability of the tumor cells. We have reported that induction rate of MMP-9 secretion correlates with metastatic potential of mouse B16 melanoma clones, and an acidic $\mathrm{pH}_{e}$ stimulates invasion through a type-IV collagen barrier $[75,86]$. In human melanoma models, an acidic $\mathrm{pH}_{e}$ increases both migration and invasiveness in vitro, accompanied by MMP-9 activation [67]. NHE1 is also associated with the metastatic ability of tumor cells; it is accumulated in leading edge of the cell and is activated by CD44 (a hyaluronan (HA) receptor) -binding to HA [94]. Because HA directs 
membrane-type 1 matrix metalloproteinase (MT1-MMP) to the invasion front (invadopodia) [95,96], NHE1 might interact with MT1-MMP through CD44 at an acidic $\mathrm{pH}_{e}[97,98]$.

Pretreatment of the tumor cells in an acidic medium induces production of proteinases (MMPs and cathepsins) and proangiogenic factors (VEGF-A and IL-8) and promotes experimental metastasis to the lung after injection into the tail vein of nude mice [5]; elevation of $\mathrm{pH}$ by one unit following injection of sodium bicarbonate prevents spontaneous metastases [99]. Furthermore, using P-31 magnetic resonance spectroscopic evaluation, it was found that acidic $\mathrm{pH}_{e}$ in spontaneous soft tissue sarcomas predicts metastasis in dogs [100].

\section{Acidic $\mathrm{pH}_{e}$ sensing systems}

ASICs are voltage-independent and proton-activated channels found in tumor cells and associated tumor malignancy [101]. Transient receptor potential (TRP) V isoforms, TRPV1, TRPV5 and TRPV6, also act as acidsensitive channels $[102,103]$. ERK1/2 plays as a downstream target of ASICs and TRPVs [104-106]. Another subfamily of TRP, TRPM7 has proton conductivity [107]. TRPM7 regulates EGF signaling to induce STAT3 activation and vimentin expression during epithelial-mesenchymal transition [108]. OGR1 also acts as a proton-sensing receptor, stimulating inositol phosphate formation [37].

\section{$\mathrm{pH}_{e}$ gradient formation by $\mathrm{H}^{+}$pumps and exchangers}

NHE1 accumulates at the leading edge to make a $\mathrm{pH}_{e}$ gradient associated with cell migration [109]. The RhoROCK pathway contributes to NHE1 activation and focal adhesions $[110,111]$. Protons stabilize the collagen $-\alpha 2 \beta 1$ integrin bond, but alkalosis, a lack of protons or an inhibited NHE activity, prevents adhesion [112]. Furthermore, the cell forms an individual $\mathrm{pH}_{e}$ gradient to facilitate movement: i.e. at leading edge or invadopodia, cells preferentially attach to the substrate due to the acidic $\mathrm{pH}_{e}$ induced by NHE1, while cell-matrix interaction at the rear end is weak due to a mid-alkaline $\mathrm{pH}_{e}$ [113]. Mutation studies clearly showed that downregulation of NHE1 function suppresses cell polarity, migration, and invasion through matrigel ${ }^{\mathrm{Ts}}$ [111]. Inhibition of NHE1 activity by HOE642 (cariporide) reduced migration and adhesion activities [109].

To secrete acidic metabolites, NHE1 and the $\mathrm{H}^{+}$-lactate co-transporter are involved [114]. $\mathrm{H}^{+}$-ATPase (the $\mathrm{H}^{+}$pump) and cell surface ATP synthase also play a role in extracellular acidification $[115,116]$, thereby contributing to tumor metastasis [3]. Therefore, inhibition of the $\mathrm{H}^{+}$pump can be a new strategy for cancer treatment [117-119]. Angiostatin has anti-tumor efficacy by inhibiting cell surface ATP synthase activity through binding its $\beta$ subunit [116]. In particular, treatment of the cells with angiostatin proved more cytotoxicity at an acidic $\mathrm{pH}_{e}$ than a neutral $\mathrm{pH}_{e}$.

\section{Drug efficacy and acidic $\mathrm{pH}_{e}$}

Two analogues of camptothecin (CPT), topotecan (TPT) and irinotecan (CPT-11), have significant anti-tumor activity in the clinic, although their abilities depend on the CPT E ring lactone, which forms an inactive hydroxy acid at physiological $\mathrm{pH}$. The reaction is reversible at an acidic $\mathrm{pH}_{e}$, which provides a rationale for selectivity because many solid tumors, while creating an acidic extracellular environment, maintain a normal intracellular $\mathrm{pH}$ [120]. An acidic $\mathrm{pH}_{e}$ inhibits cellular uptake of mitoxantrone and topotecan, so that elevation of $\mathrm{pH}_{e}$ in tumor tissue enhances those drugs' efficacy [120,121]. Because the buffer action is weaker in tumor tissue than normal tissue, $\mathrm{NaHCO}_{3}$ has much potential to raise $\mathrm{pH}_{e}$ relatively specifically in tumor tissue [122,123]. Acidic $\mathrm{pH}_{e}$ also plays a role in the resistance of tumor cells to drugs by increasing the expression of p-glycoprotein, thereby increasing drug efflux [124,125]. Recently, an acidic $\mathrm{pH}_{e}$-specific drug-releasing system has been developed [126,127]. A novel polymeric micelle constituted of 2 block copolymers of poly (L-lactic acid)-b-poly (ethylene glycol) b-poly (L-histidine) - TAT (transactivator of transcription) and poly(L-histidine)-b-poly (ethylene glycol) increases the cytotoxicity of doxorubicin in several multidrug-resistant tumor cell lines [127]. To measure $\mathrm{pH}_{e}$, a magnetic resonance image technique has been developed using acidic $\mathrm{pH}_{e}$ specific probes $[128,129]$. Thus, clinicians should pay attention to tumor $\mathrm{pH}_{e}$ in selecting drugs and helping to maximize their chemotherapeutic action. Vasodilating drugs, such as hydralazine and captopril, inhibit tumor growth rate in vivo by reducing tumor blood flow [130]. Although the reduction in tumor growth by those drugs also reduces the oxygen supply, it reduces $\mathrm{pH}_{e}$. In patients given vasodilating drugs, anti-tumor drugs with weak acidic $\mathrm{p} K_{a}$ value, such as 5-fluorouracil (5FU) and cyclophosphamide, may have increased efficacy at an acidic $\mathrm{pH}_{e}$. In contrast, the anti-tumor drugs with weak base $\mathrm{p} K_{\mathrm{a}}$ values, such as doxorubicin, mitoxantrone and daunorubicin, may not be fully functioned because acidic $\mathrm{pH}_{e}$ reduces their cytotoxicity $[121,131]$. In early-stage breast cancer, high CAIX is a predictive marker of doxorubicin resistance [132].

Because cis-diamminedichloroplatinum (II) (CDDP) solution has an acidic $\mathrm{pH}, \mathrm{NaHCO}_{3}$ is used to prevent the angialgia in the cancer patients coming from the acidic $\mathrm{pH}$ solution injection because it increases $\mathrm{pH}[133,134]$. However, CDDP is frequently used for co-injection with other chemotherapeutic drugs, such as $5 \mathrm{FU}$. In some cases, coinjection of $\mathrm{NaHCO}_{3}$ (depends on the concentration) may reduce the clinical efficacy of 5FU + CDDP regimen. 


\section{Hyperthermia and acidic $\mathrm{pH}_{e}$}

Hyperthermic treatment $\left(42.5^{\circ} \mathrm{C}\right)$ for JB-1-E plasmacytoma tumor cells in vitro enhances the colony formation index when cells are maintained at $\mathrm{pH} 6.4$, regardless oxygen tensions [135]. Melanoma cells growing at low $\mathrm{pH}$ are sensitized to hyperthermia because of the altered intracellular $\mathrm{pH}$ threshold for the heat sensitization in vitro $[136,137]$.

\section{Conclusion}

Acidic $\mathrm{pH}_{e}$ is toxic to many cells, including tumors [138]. However, if tumors have successfully adapted to their condition, and use it for their own cellular activation, this increases drug resistance and leads to more aggressive behavior. Therefore, management of tumor $\mathrm{pH}_{e}$ and inhibition of blockade of proton-sensing system are important in not only raising drug efficacy, e.g. mitoxantrone, but in preventing metastasis.

\section{Abbreviations \\ $\mathrm{pH}_{e}$ : Extracellular $\mathrm{pH}$; $\mathrm{NHE}: \mathrm{Na}^{+} / \mathrm{H}^{+}$exchanger; MCT: Monocarboxylate transporter; CA: Carbonic anhydrase; IL: Interleukin; NF-kB: Nuclear factor KB; VEGF: Vascular endothelial growth factor; HIF: Hypoxia inducible factor; LDH: Lactate dehydrogenase; OGR: Ovarian cancer G-protein-coupled receptor; PG: Prostaglandin; ASIC: Acid-sensing ion channel; KO: Knockout; FAK: Focal adhesion kinase; MMP: Matrix-metalloproteinase; iNOS: Nitric oxide synthase; PLD: Phospholipase D; MAPK: Mitogen-activated protein kinase; TNF-a: Tumor necrosis factor-a; HA: Hyaluronan; MT1-MMP: Membrane-type 1 matrix metalloproteinase; TRP: Transient receptor potential; CDDP: cis- Diamminedichloroplatinum (II).}

\section{Competing interests}

The authors declare no competing financial interests.

\section{Authors' contributions}

YK designed the study. SO, CM, YM, AS and TM were involved in discussion. YK drafted the manuscript. YB revised the manuscript. All authors read and approved the final manuscript.

\section{Acknowledgements}

We thank Profs. Masaichi-Chang-II Lee, Eiro Kubota, Kaoru Miyazaki, and Ryu-Ichiro Hata for their critical comments.

\section{Author details \\ 'Department of Oral Function and Molecular Biology, Ohu University School of Dentistry, 963-8611, Koriyama, Japan. ${ }^{2}$ Department of Oral Maxillofacial Surgery, Kanagawa Dental University Graduate School of Dentistry, Yokosuka, Japan. ${ }^{3}$ Department of Oral Science, Kanagawa Dental University Graduate School of Dentistry, Yokosuka, Japan. ${ }^{4}$ Department of General Clinical Medicine, Ohu University School of Dentistry, Koriyama, Japan.}

Received: 25 July 2013 Accepted: 29 August 2013

Published: 3 September 2013

\section{References}

1. Warburg O, Posener K, Negelein E: Über den Stoffwechsel der Tumoren (On metabolism of tumors). Biochem Z 1924, 152:319-344.

2. Chesler $M$, Nicholson C: Regulation of intracellular $\mathrm{pH}$ in vertebrate central neurons. Brain Res 1985, 325(1-2):313-316.

3. Nishisho T, Hata K, Nakanishi M, Morita Y, Sun-Wada GH, Wada Y, Yasui N, Yoneda T: The $a 3$ isoform vacuolar type $\mathrm{H}^{+}$-ATPase promotes distant metastasis in the mouse B16 melanoma cells. Mol Cancer Res 2011, 9(7):845-855.

4. Helmlinger G, Sckell A, Dellian M, Forbes NS, Jain RK: Acid production in glycolysis-impaired tumors provides new insights into tumor metabolism. Clin Cancer Res 2002, 8(4):1284-1291.
5. Rofstad EK, Mathiesen B, Kindem K, Galappathi K: Acidic extracellular pH promotes experimental metastasis of human melanoma cells in athymic nude mice. Cancer Res 2006, 66(13):6699-6707.

6. Brizel DM, Schroeder T, Scher RL, Walenta S, Clough RW, Dewhirst MW, Mueller-Klieser W: Elevated tumor lactate concentrations predict for an increased risk of metastases in head-and-neck cancer. Int J Radiat Oncol Biol Phys 2001, 51(2):349-353.

7. Walenta S, Chau TV, Schroeder T, Lehr HA, Kunz-Schughart LA, Fuerst A, Mueller-Klieser W: Metabolic classification of human rectal adenocarcinomas: a novel guideline for clinical oncologists? J Cancer Res Clin Oncol 2003, 129(6):321-326.

8. Walenta S, Salameh A, Lyng H, Evensen JF, Mitze M, Rofstad EK, Mueller-Klieser W: Correlation of high lactate levels in head and neck tumors with incidence of metastasis. Am J Pathol 1997, 150(2):409-415.

9. McFate T, Mohyeldin A, Lu H, Thakar J, Henriques J, Halim ND, Wu H, Schell MJ, Tsang TM, Teahan O, et al: Pyruvate dehydrogenase complex activity controls metabolic and malignant phenotype in cancer cells. J Biol Chem 2008, 283(33):22700-22708.

10. Fischer K, Hoffmann P, Voelkl S, Meidenbauer N, Ammer J, Edinger M, Gottfried E, Schwarz S, Rothe G, Hoves S, et al: Inhibitory effect of tumor cell-derived lactic acid on human T cells. Blood 2007, 109(9):3812-3819.

11. Yabu M, Shime H, Hara H, Saito T, Matsumoto M, Seya T, Akazawa T, Inoue N: IL-23-dependent and -independent enhancement pathways of IL-17A production by lactic acid. Int Immunol 2011, 23(1):29-41.

12. Gottfried E, Kunz-Schughart LA, Ebner S, Mueller-Klieser W, Hoves S, Andreesen R, Mackensen A, Kreutz M: Tumor-derived lactic acid modulates dendritic cell activation and antigen expression. Blood 2006, 107(5):2013-2021.

13. Goetze K, Walenta S, Ksiazkiewicz M, Kunz-Schughart LA, Mueller-Klieser W: Lactate enhances motility of tumor cells and inhibits monocyte migration and cytokine release. Int J Oncol 2011, 39(2):453-463.

14. Vegran F, Boidot $R$, Michiels $C$, Sonveaux $P$, Feron O: Lactate influx through the endothelial cell monocarboxylate transporter MCT1 supports an NF-kappaB/IL-8 pathway that drives tumor angiogenesis. Cancer Res 2011, 71(7):2550-2560.

15. Hunt TK, Aslam RS, Beckert S, Wagner S, Ghani QP, Hussain MZ, Roy S, Sen CK: Aerobically derived lactate stimulates revascularization and tissue repair via redox mechanisms. Antioxid Redox Signal 2007, 9(8):1115-1124.

16. Sattler UG, Meyer SS, Quennet V, Hoerner C, Knoerzer H, Fabian C, Yaromina A, Zips D, Walenta S, Baumann M, et al: Glycolytic metabolism and tumour response to fractionated irradiation. Radiother Oncol 2010, 94(1):102-109.

17. Sonveaux P, Copetti T, De Saedeleer CJ, Vegran F, Verrax J, Kennedy KM, Moon EJ, Dhup S, Danhier P, Frerart F, et al: Targeting the lactate transporter MCT1 in endothelial cells inhibits lactate-induced HIF-1 activation and tumor angiogenesis. PLoS One 2012, 7(3):e33418.

18. Kim JH, Kim SH, Alfieri AA, Young CW: Quercetin, an inhibitor of lactate transport and a hyperthermic sensitizer of HeLa cells. Cancer Res 1984, 44(1):102-106.

19. Hatanaka $M$, Hanafusa $\mathrm{H}$ : Analysis of a functional change in membrane in the process of cell transformation by Rous sarcoma virus; alteration in the characteristics of sugar transport. Virology 1970, 41(4):647-652.

20. Kallinowski $F$, Vaupel $P$ : Concurrent measurements of $\mathrm{O}_{2}$ partial pressures and $\mathrm{pH}$ values in human mammary carcinoma xenotransplants. Adv Exp Med Biol 1986, 200:609-621.

21. Martin GR, Jain RK: Noninvasive measurement of interstitial pH profiles in normal and neoplastic tissue using fluorescence ratio imaging microscopy. Cancer Res 1994, 54(21):5670-5674.

22. Helmlinger $G$, Yuan $F$, Dellian $M$, Jain RK: Interstitial $\mathrm{pH}$ and $\mathrm{pO}_{2}$ gradients in solid tumors in vivo: high-resolution measurements reveal a lack of correlation. Nat Med 1997, 3(2):177-182.

23. Kayser G, Kassem A, Sienel W, Schulte-Uentrop L, Mattern D, Aumann K, Stickeler E, Werner M, Passlick B, Zur Hausen A: Lactate-dehydrogenase 5 is overexpressed in non-small cell lung cancer and correlates with the expression of the transketolase-like protein 1. Diagn Pathol 2010, 5:22.

24. Koukourakis MI, Giatromanolaki A, Sivridis E, Bougioukas G, Didilis V, Gatter KC, Harris AL: Lactate dehydrogenase-5 (LDH-5) overexpression in non-small-cell lung cancer tissues is linked to tumour hypoxia, angiogenic factor production and poor prognosis. Br J Cancer 2003, 89(5):877-885.

25. Koukourakis MI, Giatromanolaki A, Simopoulos C, Polychronidis A, Sivridis E: Lactate dehydrogenase $5(\mathrm{LDH} 5)$ relates to up-regulated hypoxia 
inducible factor pathway and metastasis in colorectal cancer. Clin Exp Metastasis 2005, 22(1):25-30.

26. Koukourakis MI, Giatromanolaki A, Sivridis E, Gatter KC, Harris AL: Lactate dehydrogenase 5 expression in operable colorectal cancer: strong association with survival and activated vascular endothelial growth factor pathway-a report of the Tumour Angiogenesis Research Group. J Clin Oncol 2006, 24(26):4301-4308.

27. Koukourakis MI, Giatromanolaki A, Sivridis E, Gatter KC, Trarbach T, Folprecht G, Shi MM, Lebwohl D, Jalava T, Laurent D, et al: Prognostic and predictive role of lactate dehydrogenase 5 expression in colorectal cancer patients treated with PTK787/ZK 222584 (vatalanib) antiangiogenic therapy. Clin Cancer Res 2011, 17(14):4892-4900.

28. Baron R, Neff L, Louvard D, Courtoy PJ: Cell-mediated extracellular acidification and bone resorption: evidence for a low $\mathrm{pH}$ in resorbing lacunae and localization of a $100-\mathrm{kD}$ lysosomal membrane protein at the osteoclast ruffled border. J Cell Biol 1985, 101(6):2210-2222.

29. Lehenkari P, Hentunen TA, Laitala-Leinonen T, Tuukkanen J, Vaananen HK: Carbonic anhydrase II plays a major role in osteoclast differentiation and bone resorption by effecting the steady state intracellular $\mathrm{pH}$ and $\mathrm{Ca}^{2+}$. Exp Cell Res 1998, 242(1):128-137.

30. Mobasheri A, Golding S, Pagakis SN, Corkey K, Pocock AE, Fermor B, O'Brien MJ, Wilkins RJ, Ellory JC, Francis MJ: Expression of cation exchanger NHE and anion exchanger $\mathrm{AE}$ isoforms in primary human bone-derived osteoblasts. Cell Biol Int 1998, 22(7-8):551-562.

31. Biskobing DM, Fan D: Acid pH increases carbonic anhydrase II and calcitonin receptor mRNA expression in mature osteoclasts. Calcif Tissue Int 2000, 67(2):178-183.

32. Häbler C: Über den K- und Ca-Gehalt von eiter und Exsudaten und seine Beziehungen zum Entzündungsschmerz. Klin Wochenschrift 1929, 8:1569-1572.

33. Dellian $M$, Helmlinger $G$, Yuan $F$, Jain RK: Fluorescence ratio imaging of interstitial pH in solid tumours: effect of glucose on spatial and temporal gradients. Br J Cancer 1996, 74(8):1206-1215.

34. Rocha-Gonzalez HI, Herrejon-Abreu EB, Lopez-Santillan FJ, Garcia-Lopez BE, Murbartian J, Granados-Soto V: Acid increases inflammatory pain in rats: Effect of local peripheral ASICs inhibitors. Eur J Pharmacol 2009, 603(1-3):56-61.

35. Steen $\mathrm{KH}$, Issberner U, Reeh PW: Pain due to experimental acidosis in human skin: evidence for non-adapting nociceptor excitation. Neurosci Lett 1995, 199(1):29-32

36. Nagae M, Hiraga T, Yoneda T: Acidic microenvironment created by osteoclasts causes bone pain associated with tumor colonization. J Bone Miner Metab 2007, 25(2):99-104

37. Ludwig MG, Vanek M, Guerini D, Gasser JA, Jones CE, Junker U, Hofstetter $H$, Wolf RM, Seuwen K: Proton-sensing G-protein-coupled receptors. Nature 2003, 425(6953):93-98.

38. Tomura H, Wang JQ, Liu JP, Komachi M, Damirin A, Mogi C, Tobo M, Nochi H, Tamoto K, Im DS, et al: Cyclooxygenase-2 expression and prostaglandin $E_{2}$ production in response to acidic $\mathrm{pH}$ through OGR1 in a human osteoblastic cell line. J Bone Miner Res 2008, 23(7):1129-1139.

39. Kobayashi Y, Mizoguchi T, Take I, Kurihara S, Udagawa N, Takahashi N: Prostaglandin $E_{2}$ enhances osteoclastic differentiation of precursor cells through protein kinase A-dependent phosphorylation of TAK1. J Biol Chem 2005, 280(12):11395-11403.

40. Iwai K, Koike M, Ohshima S, Miyatake K, Uchiyama Y, Saeki Y, Ishii M: RGS18 acts as a negative regulator of osteoclastogenesis by modulating the acid-sensing OGR1/NFAT signaling pathway. J Bone Miner Res 2007, 22(10):1612-1620.

41. Ihara Y, Kihara Y, Hamano F, Yanagida K, Morishita Y, Kunita A, Yamori T, Fukayama M, Aburatani H, Shimizu T, et al: The G protein-coupled receptor T-cell death-associated gene 8 (TDAG8) facilitates tumor development by serving as an extracellular pH sensor. Proc Natl Acad Sci U S A 2010, 107(40):17309-17314.

42. He XD, Tobo M, Mogi C, Nakakura T, Komachi M, Murata N, Takano M, Tomura H, Sato K, Okajima F: Involvement of proton-sensing receptor TDAG8 in the anti-inflammatory actions of dexamethasone in peritoneal macrophages. Biochem Biophys Res Commun 2011, 415(4):627-631.

43. Nagae M, Hiraga T, Wakabayashi H, Wang L, Iwata K, Yoneda T: Osteoclasts play a part in pain due to the inflammation adjacent to bone. Bone 2006, 39(5):1107-1115.
44. Jasti J, Furukawa H, Gonzales EB, Gouaux E: Structure of acid-sensing ion channel 1 at 1.9 A resolution and low pH. Nature 2007, 449(7160):316-323.

45. Marples MJ: The ecology of human skin. Springfield, IL: Charles C. Thomas; 1965.

46. Behne MJ, Barry NP, Hanson KM, Aronchik I, Clegg RW, Gratton E, Feingold K, Holleran WM, Elias PM, Mauro TM: Neonatal development of the stratum corneum $\mathrm{pH}$ gradient: localization and mechanisms leading to emergence of optimal barrier function. J Invest Dermatol 2003, 120(6):998-1006.

47. Ilic D, Mao-Qiang M, Crumrine D, Dolganov G, Larocque N, Xu P, Demerjian M, Brown BE, Lim ST, Ossovskaya V, et al: Focal adhesion kinase controls $\mathrm{pH}$-dependent epidermal barrier homeostasis by regulating actin-directed $\mathrm{Na}^{+} / \mathrm{H}^{+}$exchanger 1 plasma membrane localization. Am J Pathol 2007, 170(6):2055-2067.

48. Adamson TM, Boyd RD, Platt HS, Strang LB: Composition of alveolar liquid in the foetal lamb. J Physiol 1969, 204(1):159-168.

49. Tate S, MacGregor G, Davis M, Innes JA, Greening AP: Airways in cystic fibrosis are acidified: detection by exhaled breath condensate. Thorax 2002, 57(11):926-929.

50. Ricciardolo FL, Gaston B, Hunt J: Acid stress in the pathology of asthma. J Allergy Clin Immunol 2004, 113(4):610-619.

51. Bekku S, Mochizuki H, Yamamoto T, Ueno H, Takayama E, Tadakuma T: Expression of carbonic anhydrase I or II and correlation to clinical aspects of colorectal cancer. Hepatogastroenterology 2000, 47(34):998-1001.

52. Leppilampi M, Koistinen P, Savolainen ER, Hannuksela J, Parkkila AK, Niemela O, Pastorekova S, Pastorek J, Waheed A, Sly WS, et al: The expression of carbonic anhydrase II in hematological malignancies. Clin Cancer Res 2002, 8(7):2240-2245.

53. Chiche J, Ilc K, Laferriere J, Trottier E, Dayan F, Mazure NM, Brahimi-Horn MC, Pouyssegur J: Hypoxia-inducible carbonic anhydrase IX and XII promote tumor cell growth by counteracting acidosis through the regulation of the intracellular pH. Cancer Res 2009, 69(1):358-368.

54. Brockton NT, Klimowicz AC, Bose P, Petrillo SK, Konno M, Rudmik L, Dean M, Nakoneshny SC, Matthews TW, Chandarana S, et al: High stromal carbonic anhydrase IX expression is associated with nodal metastasis and decreased survival in patients with surgically-treated oral cavity squamous cell carcinoma. Oral Oncol 2012, 48(7):615-622.

55. Parkkila S, Parkkila AK, Saarnio J, Kivela J, Karttunen TJ, Kaunisto K, Waheed A, Sly WS, Tureci O, Virtanen I, et al: Expression of the membrane-associated carbonic anhydrase isozyme XII in the human kidney and renal tumors. $J$ Histochem Cytochem 2000, 48(12):1601-1608.

56. Kummola L, Hamalainen JM, Kivela J, Kivela AJ, Saarnio J, Karttunen T, Parkkila S: Expression of a novel carbonic anhydrase, CA XIII, in normal and neoplastic colorectal mucosa. BMC cancer 2005, 5:41.

57. Swietach P, Wigfield $S$, Cobden $P$, Supuran $C T$, Harris AL, Vaughan-Jones RD: Tumor-associated carbonic anhydrase 9 spatially coordinates intracellular $\mathrm{pH}$ in three-dimensional multicellular growths. J Biol Chem 2008, 283(29):20473-20483.

58. Williams E, Martin S, Moss R, Durrant L, Deen S: Co-expression of VEGF and CA9 in ovarian high-grade serous carcinoma and relationship to survival. Virchows Arch 2012, 461(1):33-39.

59. Shin HJ, Rho SB, Jung DC, Han IO, Oh ES, Kim JY: Carbonic anhydrase IX (CA9) modulates tumor-associated cell migration and invasion. J Cell SCi 2011, 124(Pt 7):1077-1087.

60. Parkkila S, Rajaniemi H, Parkkila AK, Kivela J, Waheed A, Pastorekova S, Pastorek J, Sly WS: Carbonic anhydrase inhibitor suppresses invasion of renal cancer cells in vitro. Proc Natl Acad Sci U S A 2000, 97(5):2220-2224.

61. Zatovicova M, Jelenska L, Hulikova A, Csaderova L, Ditte Z, Ditte P, Goliasova T, Pastorek J, Pastorekova S: Carbonic anhydrase IX as an anticancer therapy target: preclinical evaluation of internalizing monoclonal antibody directed to catalytic domain. Curr Pharm Des 2010, 16(29):3255-3263.

62. Muselaers S, Mulders P, Oosterwijk E, Oyen W, Boerman O: Molecular imaging and carbonic anhydrase IX-targeted radioimmunotherapy in clear cell renal cell carcinoma. Immunotherapy 2013, 5(5):489-495.

63. Oosterwijk-Wakka JC, Boerman OC, Mulders PF, Oosterwijk E: Application of Monoclonal Antibody G250 Recognizing Carbonic Anhydrase IX in Renal Cell Carcinoma. Int J Mol Sci 2013, 14(6):11402-11423.

64. Tjäderhane L, Larjava H, Sorsa T, Uitto VJ, Larmas M, Salo T: The activation and function of host matrix metalloproteinases in dentin matrix breakdown in caries lesions. J Dent Res 1998, 77(8):1622-1629.

65. Davis GE, Martin BM: A latent $M_{\mathrm{r}} 94,000$ gelatin-degrading metalloprotease induced during differentiation of HL-60 
promyelocytic leukemia cells: a member of the collagenase family of enzymes. Cancer Res 1990, 50(4):1113-1120.

66. Davis GE: Identification of an abundant latent $94-k D a$ gelatin-degrading metalloprotease in human saliva which is activated by acid exposure: implications for a role in digestion of collagenous proteins. Arch Biochem Biophys 1991, 286(2):551-554

67. Martinez-Zaguilan R, Seftor EA, Seftor RE, Chu YW, Gillies RJ, Hendrix MJ: Acidic $\mathrm{pH}$ enhances the invasive behavior of human melanoma cells. Clin Exp Metastasis 1996, 14(2):176-186.

68. Karsdal MA, Henriksen K, Sorensen MG, Gram J, Schaller S, Dziegiel MH, Heegaard AM, Christophersen P, Martin TJ, Christiansen C, et al: Acidification of the osteoclastic resorption compartment provides insight into the coupling of bone formation to bone resorption. Am J Pathol 2005, 166(2):467-476.

69. Saftig P, Hunziker E, Wehmeyer O, Jones S, Boyde A, Rommerskirch W, Moritz JD, Schu P, Von Figura K: Impaired osteoclastic bone resorption leads to osteopetrosis in cathepsin-K-deficient mice. Proc Natl Acad Sci U S A 1998, 95(23):13453-13458.

70. Le Gall C, Bellahcene A, Bonnelye E, Gasser JA, Castronovo V, Green J, Zimmermann J, Clezardin P: A cathepsin $\mathrm{K}$ inhibitor reduces breast cancer induced osteolysis and skeletal tumor burden. Cancer Res 2007, 67(20):9894-9902.

71. Podgorski I, Linebaugh BE, Koblinski JE, Rudy DL, Herroon MK, Olive MB, Sloane BF: Bone marrow-derived cathepsin K cleaves SPARC in bone metastasis. Am J Pathol 2009, 175(3):1255-1269.

72. Nakajima M, Irimura T, Di Ferrante D, Di Ferrante N, Nicolson GL: Heparan sulfate degradation: relation to tumor invasive and metastatic properties of mouse B16 melanoma sublines. Science 1983, 220(4597):611-613.

73. Nakajima M, Irimura T, Di Ferrante N, Nicolson GL: Metastatic melanoma cell heparanase. Characterization of heparan sulfate degradation fragments produced by B16 melanoma endoglucuronidase. J Biol Chem 1984, 259(4):2283-2290.

74. Kato Y, Ozawa S, Tsukuda M, Kubota E, Miyazaki K, St-Pierre Y, Hata R: Acidic extracellular $\mathrm{pH}$ increases calcium influx-triggered phospholipase D activity along with acidic sphingomyelinase activation to induce matrix metalloproteinase-9 expression in mouse metastatic melanoma. FEBS J 2007, 274(12):3171-3183.

75. Kato Y, Nakayama Y, Umeda M, Miyazaki K: Induction of 103-kDa gelatinase/type IV collagenase by acidic culture conditions in mouse metastatic melanoma cell lines. J Biol Chem 1992, 267(16):11424-11430.

76. Griffiths L, Dachs GU, Bicknell R, Harris AL, Stratford IJ: The influence of oxygen tension and $\mathrm{pH}$ on the expression of platelet-derived endothelial cell growth factor/thymidine phosphorylase in human breast tumor cells grown in vitro and in vivo. Cancer Res 1997, 57(4):570-572.

77. Bellocq A, Suberville S, Philippe C, Bertrand F, Perez J, Fouqueray B, Cherqui G, Baud $\mathrm{L}$ : Low environmental $\mathrm{pH}$ is responsible for the induction of nitric-oxide synthase in macrophages. Evidence for involvement of nuclear factor-kB activation. J Biol Chem 1998, 273(9):5086-5092.

78. Fukumura D, Xu L, Chen Y, Gohongi T, Seed B, Jain RK: Hypoxia and acidosis independently up-regulate vascular endothelial growth factor transcription in brain tumors in vivo. Cancer Res 2001, 61(16):6020-6024.

79. Xu L, Fukumura D, Jain RK: Acidic extracellular $\mathrm{pH}$ induces vascular endothelial growth factor (VEGF) in human glioblastoma cells via ERK1/2 MAPK signaling pathway: mechanism of low pH-induced VEGF. J Biol Chem 2002, 277(13):11368-11374

80. Shi Q, Abbruzzese JL, Huang S, Fidler IJ, Xiong Q, Xie K: Constitutive and inducible interleukin 8 expression by hypoxia and acidosis renders human pancreatic cancer cells more tumorigenic and metastatic. Clin Cancer Res 1999, 5(11):3711-3721.

81. Shi Q, Le X, Wang B, Xiong Q, Abbruzzese JL, Xie K: Regulation of interleukin-8 expression by cellular $\mathrm{pH}$ in human pancreatic adenocarcinoma cells. J Interferon Cytokine Res 2000, 20(11):1023-1028.

82. Shi Q, Xiong Q, Le X, Xie K: Regulation of interleukin-8 expression by tumor-associated stress factors. J Interferon Cytokine Res 2001, 21(8):553-566.

83. $\mathrm{Xu} \mathrm{L}$, Fidler IJ: Acidic $\mathrm{pH}$-induced elevation in interleukin 8 expression by human ovarian carcinoma cells. Cancer Res 2000, 60(16):4610-4616.

84. Shi Q, Le X, Wang B, Abbruzzese JL, Xiong Q, He Y, Xie K: Regulation of vascular endothelial growth factor expression by acidosis in human cancer cells. Oncogene 2001, 20(28):3751-3756.

85. Bischoff DS, Zhu JH, Makhijani NS, Yamaguchi DT: Acidic pH stimulates the production of the angiogenic CXC chemokine, CXCL8 (interleukin-8), in human adult mesenchymal stem cells via the extracellular signalregulated kinase, p38 mitogen-activated protein kinase, and NF-KB pathways. J Cell Biochem 2008, 104(4):1378-1392.

86. Kato $Y$, Ozono S, Shuin T, Miyazaki K: Slow induction of gelatinase B mRNA by acidic culture conditions in mouse metastatic melanoma cells. Cell Biol Int 1996, 20(5):375-377.

87. Kato Y, Lambert CA, Colige AC, Mineur P, Noël A, Frankenne F, Foidart JM, Baba M, Hata Rl, Miyazaki K, et al: Acidic extracellular pH induces matrix metalloproteinase- 9 expression in mouse metastatic melanoma cells through the phospholipase D-mitogen-activated protein kinase signaling. J Biol Chem 2005, 280(12):10938-10944.

88. Itatsu K, Sasaki M, Harada K, Yamaguchi J, Ikeda H, Sato Y, Ohta T, Sato H, Nagino M, Nimura $Y$, et al: Phosphorylation of extracellular signalregulated kinase $1 / 2$, p38 mitogen-activated protein kinase and nuclear translocation of nuclear factor- $\mathrm{KB}$ are involved in upregulation of matrix metalloproteinase-9 by tumour necrosis factor-a. Liver Int 2009, 29(2):291-298

89. Hirata S, Fukamachi T, Sakano H, Tarora A, Saito H, Kobayashi H: Extracellular acidic environments induce phosphorylation of ZAP-70 in Jurkat T cells. Immunol Lett 2008, 115(2):105-109.

90. Tomura H, Wang JQ, Komachi M, Damirin A, Mogi C, Tobo M, Kon J, Misawa N, Sato K, Okajima F: Prostaglandin $\mathrm{I}_{2}$ production and CAMP accumulation in response to acidic extracellular pH through OGR1 in human aortic smooth muscle cells. J Biol Chem 2005, 280(41):34458-34464.

91. Torigoe T, Izumi H, Yoshida Y, Ishiguchi H, Okamoto T, Itoh H, Kohno K: Low $\mathrm{pH}$ enhances Sp1 DNA binding activity and interaction with TBP. Nucleic Acids Res 2003, 31(15):4523-4530.

92. Chen Y, Chen CH, Tung PY, Huang SH, Wang SM: An acidic extracellular $\mathrm{pH}$ disrupts adherens junctions in HepG2 cells by Src kinases-dependent modification of E-cadherin. J Cell Biochem 2009, 108(4):851-859.

93. Chen $\mathrm{Y}$, Kung HN, Chen $\mathrm{CH}$, Huang SH, Chen KH, Wang SM: Acidic extracellular $\mathrm{pH}$ induces p120-catenin-mediated disruption of adherens junctions via the Src kinase-PKCס pathway. FEBS Lett 2011, 585(4):705-710.

94. Bourguignon LY, Singleton PA, Diedrich F, Stern R, Gilad E: CD44 interaction with $\mathrm{Na}^{+}-\mathrm{H}^{+}$exchanger (NHE1) creates acidic microenvironments leading to hyaluronidase- 2 and cathepsin B activation and breast tumor cell invasion. J Biol Chem 2004, 279(26):26991-27007.

95. Mori H, Tomari T, Koshikawa N, Kajita M, Itoh Y, Sato H, Tojo H, Yana I, Seiki M: CD44 directs membrane-type 1 matrix metalloproteinase to lamellipodia by associating with its hemopexin-like domain. EMBO J 2002, 21(15):3949-3959.

96. Suenaga N, Mori H, Itoh Y, Seiki M: CD44 binding through the hemopexinlike domain is critical for its shedding by membrane-type 1 matrix metalloproteinase. Oncogene 2005, 24(5):859-868.

97. Lin Y, Chang G, Wang J, Jin W, Wang L, Li H, Ma L, Li Q, Pang T: NHE1 mediates MDA-MB-231 cells invasion through the regulation of MT1MMP. Exp Cell Res 2011, 317(14):2031-2040.

98. Lin Y, Wang J, Jin W, Wang L, Li H, Ma L, Li Q, Pang T: NHE1 mediates migration and invasion of HeLa cells via regulating the expression and localization of MT1-MMP. Cell Biochem Funct 2012, 1:41-46.

99. Robey IF, Baggett BK, Kirkpatrick ND, Roe DJ, Dosescu J, Sloane BF, Hashim Al, Morse DL, Raghunand N, Gatenby RA, et al: Bicarbonate increases tumor pH and inhibits spontaneous metastases. Cancer Res 2009, 69(6):2260-2268.

100. Lora-Michiels M, Yu D, Sanders L, Poulson JM, Azuma C, Case B, Vujaskovic Z, Thrall DE, Charles HC, Dewhirst MW: Extracellular pH and P-31 magnetic resonance spectroscopic variables are related to outcome in canine soft tissue sarcomas treated with thermoradiotherapy. Clin Cancer Res 2006, 12(19):5733-5740.

101. Berdiev BK, Xia J, McLean LA, Markert JM, Gillespie GY, Mapstone TB, Naren AP, Jovov B, Bubien JK, Ji HL, et al: Acid-sensing ion channels in malignant gliomas. J Biol Chem 2003, 278(17):15023-15034.

102. Ohta T, Imagawa T, Ito S: Novel gating and sensitizing mechanism of capsaicin receptor (TRPV1): tonic inhibitory regulation of extracellular sodium through the external protonation sites on TRPV1. J Biol Chem 2008, 283(14):9377-9387.

103. Nakaya K, Harbidge DG, Wangemann P, Schultz BD, Green ED, Wall SM, Marcus DC: Lack of pendrin $\mathrm{HCO}_{3}^{-}$transport elevates vestibular endolymphatic $\left[\mathrm{Ca}^{2+}\right]$ by inhibition of acid-sensitive TRPV5 and TRPV6 channels. Am J Physiol Renal Physiol 2007, 292(5):F1314-F1321.

104. Chen Y, Willcockson HH, Valtschanoff JG: Vanilloid receptor TRPV1-mediated phosphorylation of ERK in murine adjuvant arthritis. Osteoarthritis Cartilage 2009, 17(2):244-251. 
105. Chen Y, Williams SH, McNulty AL, Hong JH, Lee SH, Rothfusz NE, Parekh PK, Moore C, Gereau RW, Taylor AB, et al: Temporomandibular joint pain: A critical role for Trpv4 in the trigeminal ganglion. Pain 2013, 154(8):1295-1304.

106. Wang G, Su J, Li L, Feng J, Shi L, He W, Liu Y: Edaravone alleviates hypoxia-acidosis/reoxygenation-induced neuronal injury by activating ERK1/2. Neurosci Lett 2013, 543:72-77.

107. Numata T, Okada Y: Proton conductivity through the human TRPM7 channel and its molecular determinants. J Biol Chem 2008, 283(22):15097-15103.

108. Davis FM, Azimi I, Faville RA, Peters AA, Jalink K, Putney JW Jr, Goodhill GJ, Thompson EW, Roberts-Thomson SJ, Monteith GR: Induction of epithelialmesenchymal transition (EMT) in breast cancer cells is calcium signal dependent. Oncogene 2013, in press.

109. Stüwe L, Müller M, Fabian A, Waning J, Mally S, Noël J, Schwab A, Stock C: $\mathrm{pH}$ dependence of melanoma cell migration: protons extruded by NHE1 dominate protons of the bulk solution. J Physiol 2007, 585(Pt 2):351-360.

110. Tominaga T, Barber DL: Na-H exchange acts downstream of RhoA to regulate integrin-induced cell adhesion and spreading. Mol Biol Cell 1998, 9(8):2287-2303.

111. Denker SP, Barber DL: Cell migration requires both ion translocation and cytoskeletal anchoring by the $\mathrm{Na}-\mathrm{H}$ exchanger NHE1. J Cell Biol 2002, 159(6):1087-1096.

112. Stock C, Gassner B, Hauck CR, Arnold H, Mally S, Eble JA, Dieterich P, Schwab A: Migration of human melanoma cells depends on extracellular $\mathrm{pH}$ and $\mathrm{Na}^{+} / \mathrm{H}^{+}$exchange. J Physiol 2005, 567(Pt 1):225-238.

113. Krahling H, Mally S, Eble JA, Noel J, Schwab A, Stock C: The glycocalyx maintains a cell surface $\mathrm{pH}$ nanoenvironment crucial for integrin-mediated migration of human melanoma cells. Pflugers Arch 2009, 458(6):1069-1083.

114. Cardone RA, Casavola V, Reshkin SJ: The role of disturbed pH dynamics and the $\mathrm{Na}^{+} / \mathrm{H}^{+}$exchanger in metastasis. Nat Rev Cancer 2005, 5(10):786-795.

115. Montcourrier P, Silver I, Farnoud R, Bird I, Rochefort H: Breast cancer cells have a high capacity to acidify extracellular milieu by a dual mechanism. Clin Exp Metastasis 1997, 15(4):382-392.

116. Chi SL, Pizzo SV: Angiostatin is directly cytotoxic to tumor cells at low extracellular $\mathrm{pH}$ : a mechanism dependent on cell surface-associated ATP synthase. Cancer Res 2006, 66(2):875-882.

117. Spugnini EP, Citro G, Fais S: Proton pump inhibitors as anti vacuolar-ATPases drugs: a novel anticancer strategy. J Exp Clin Cancer Res 2010, 29:44.

118. De Milito A, Canese R, Marino ML, Borghi M, lero M, Villa A, Venturi G, Lozupone F, lessi E, Logozzi M, et al: pH-dependent antitumor activity of proton pump inhibitors against human melanoma is mediated by inhibition of tumor acidity. Int J Cancer 2010, 127(1):207-219.

119. Wiedmann RM, Von Schwarzenberg K, Palamidessi A, Schreiner $L$, Kubisch $R$, Liebl J, Schempp C, Trauner D, Vereb G, Zahler S, et al: The V-ATPase-inhibitor archazolid abrogates tumor metastasis via inhibition of endocytic activation of the Rho-GTPase Rac1. Cancer Res 2012, 72(22):5976-5987.

120. Adams DJ, Dewhirst MW, Flowers JL, Gamcsik MP, Colvin OM, Manikumar G, Wani MC, Wall ME: Camptothecin analogues with enhanced antitumor activity at acidic pH. Cancer Chemother Pharmacol 2000, 46(4):263-271.

121. Vukovic V, Tannock IF: Influence of low pH on cytotoxicity of paclitaxel, mitoxantrone and topotecan. Br J Cancer 1997, 75(8):1167-1172.

122. Raghunand N, He X, Van Sluis R, Mahoney B, Baggett B, Taylor CW, Paine-Murrieta G, Roe D, Bhujwalla ZM, Gillies RJ: Enhancement of chemotherapy by manipulation of tumour pH. Br J Cancer 1999, 80(7):1005-1011.

123. Raghunand N, Mahoney B, Van Sluis R, Baggett B, Gillies RJ: Acute metabolic alkalosis enhances response of $\mathrm{C} 3 \mathrm{H}$ mouse mammary tumors to the weak base mitoxantrone. Neoplasia 2001, 3(3):227-235.

124. Lotz C, Kelleher DK, Gassner B, Gekle M, Vaupel P, Thews O: Role of the tumor microenvironment in the activity and expression of the p-glycoprotein in human colon carcinoma cells. Oncol Rep 2007, 17(1):239-244.

125. Thews O, Dillenburg W, Rosch F, Fellner M: PET imaging of the impact of extracellular $\mathrm{pH}$ and MAP kinases on the p-glycoprotein (Pgp) activity. Adv Exp Med Biol 2013, 765:279-286.

126. Ko J, Park K, Kim YS, Kim MS, Han JK, Kim K, Park RW, Kim IS, Song HK, Lee DS, et al: Tumoral acidic extracellular $\mathrm{pH}$ targeting of $\mathrm{pH}$-responsive MPEG-poly ( $\beta$-amino ester) block copolymer micelles for cancer therapy. J Control Release 2007, 123(2):109-115.

127. Lee ES, Gao Z, Kim D, Park K, Kwon IC, Bae YH: Super pH-sensitive multifunctional polymeric micelle for tumor $\mathrm{pH}_{e}$ specific TAT exposure and multidrug resistance. J Control Release 2008, 129(3):228-236.
128. Garcia-Martin ML, Martinez GV, Raghunand N, Sherry AD, Zhang S, Gillies RJ: High resolution $\mathrm{pH}_{e}$ imaging of rat glioma using $\mathrm{pH}$-dependent relaxivity. Magn Reson Med 2006, 55(2):309-315.

129. Van Sluis R, Bhujwalla ZM, Raghunand N, Ballesteros P, Alvarez J, Cerdan S, Galons JP, Gillies RJ: In vivo imaging of extracellular $\mathrm{pH}$ using ${ }^{1} \mathrm{H}$ MRSI. Magn Reson Med 1999, 41(4):743-750.

130. Adachi $\mathrm{E}$, Tannock IF: The effects of vasodilating drugs on $\mathrm{pH}$ in tumors. Oncol Res 1999, 11(4):179-185.

131. Raghunand N, Mahoney BP, Gillies RJ: Tumor acidity, ion trapping and chemotherapeutics. II. pH-dependent partition coefficients predict importance of ion trapping on pharmacokinetics of weakly basic chemotherapeutic agents. Biochem Pharmacol 2003, 66(7):1219-1229.

132. Betof AS, Rabbani ZN, Hardee ME, Kim SJ, Broadwater G, Bentley RC, Snyder SA, Vujaskovic Z, Oosterwijk E, Harris LN, et al: Carbonic anhydrase IX is a predictive marker of doxorubicin resistance in early-stage breast cancer independent of HER2 and TOP2A amplification. Br J Cancer 2012, 106(5):916-922.

133. Teh BG, Kobayashi W, Narita K, Fukui R, Kimura H: Superselective docetaxel-nedaplatin combined infusion concurrent with radiation thrapy in advanced oral cancers. Oral Oncol EXTRA 2004, 40:126-131.

134. Shiga K, Yokoyama J, Hashimoto S, Saijo S, Tateda M, Ogawa T, Watanabe $M$, Kobayashi T: Combined therapy after superselective arterial cisplatin infusion to treat maxillary squamous cell carcinoma. Otolaryngol Head Neck Surg 2007, 136(6):1003-1009.

135. Overgaard J, Bichel P: The influence of hypoxia and acidity on the hyperthermic response of malignant cells in vitro. Radiology 1977, 123(2):511-514.

136. Coss RA, Storck CW, Daskalakis C, Berd D, Wahl ML: Intracellular acidification abrogates the heat shock response and compromises survival of human melanoma cells. Mol Cancer Ther 2003, 2(4):383-388.

137. Coss RA, Storck CW, Wachsberger PR, Reilly J, Leeper DB, Berd D, Wahl ML: Acute extracellular acidification reduces intracellular $\mathrm{pH}, 42^{\circ} \mathrm{C}$-induction of heat shock proteins and clonal survival of human melanoma cells grown at pH 6.7. Int J Hyperthermia 2004, 20(1):93-106.

138. Lan A, Lagadic-Gossmann D, Lemaire C, Brenner C, Jan G: Acidic extracellular $\mathrm{pH}$ shifts colorectal cancer cell death from apoptosis to necrosis upon exposure to propionate and acetate, major end-products of the human probiotic propionibacteria. Apoptosis 2007, 12(3):573-591.

doi:10.1186/1475-2867-13-89

Cite this article as: Kato et al:: Acidic extracellular microenvironment and cancer. Cancer Cell International 2013 13:89.

\section{Submit your next manuscript to BioMed Central and take full advantage of:}

- Convenient online submission

- Thorough peer review

- No space constraints or color figure charges

- Immediate publication on acceptance

- Inclusion in PubMed, CAS, Scopus and Google Scholar

- Research which is freely available for redistribution 